\title{
THE CEREBRAL FISSURES OF THE ATLANTIC WALRUS.
}

\author{
By Pierre A. Fish, \\ Of Cornell University, Ithaca, New York.
}

Through the courtesy of the officials of the U. S. National Museum there were sent to me, for examination and description, two walrus brains obtained for that institution by R. Stein at North Greenland, August 10, 1901. The specimens had been preserved in a fluid of which formaldehyde was apparently a constituent. In both brains the cerebellum had been removed by a sectic n through the brain stem at the level of the junction of the optic thalami with the mesencephal, so that in the process of removal the epiphysis (pineal body) remained attached to the cerebellar portion; the two hemicerebrums were then divided by a median section.

The two brains differed quite markedly in size, the one being but slightly more than half as large as the other. The smaller of the two brains had suffered quite material mutilation during its removal from the cranium, a considerable portion of the brain substance having been lost from the right hemicerebrum. In the process of hardening all of the hemicerebrums had undergone considerable distortion. The mesal surface in each case, instead of being relatively flat, was very distinctly convex in its cephalo-caudal direction, and on this account the gyres (convolutions) and fissures of the lateral aspect were closely crowded together, rendering the study of these parts more difficult. On this account, also, it was decided not to photograph the brains, as the relationship of the parts would be misleading and tend to cause error and confusion to the observer. The figures which illustrate this article were sketched free-hand, the parts at the same time being manipulated so as to bring them as nearly as possible to their normal relations. By carefully verifying each part on the brain itself as the drawing progressed, it is believed the figures may be accepted as representing with approximate accuracy the normal relationship of the more important parts.

Weight.-Turner a gives the weights of three walrus brains "after

a Challenger Reports, Zoology, XXVI, 1888, pp. 89-134. 
the removal of the membranes and hardening in spirit." Brain A weighed 24 ounces 7 drams avoirdupois; B $13 \frac{1}{2}$ ounces, and C 26 ounces. In the specimens examined by me only the larger of the two brains was weighed, all of the membranes having been removed from the cerebrum, but not from the cerebellum and the brain stem adjacent to it, the pia and arachnoid still adhering. The total weight of the brain under these conditions was 29 ounces avoirdupois. The weight of the cerebrum without the pia was $22 \frac{3}{4}$ ounces, leaving a weight of $6 \frac{1}{4}$ ounces for the cerebellum, oblongata, mesencephal, and epiphysis, the latter having adhered to the cerebellum. Turner has called attention to the remarkable size and leaf-like or pyriform shape of the epiphysis (pineal body) in the walrus, but does not mention its weight. In my specimen it weighed 1 dram, 1 scruple, and 3 grains, or a total of 83 grains.

\section{FISSURES AND GYRES.}

The olfactory fissure is scarcely represented; a slight, short depression at the attachment of the olfactory peduncle is all that can be found. The olfactory bulbs were missing, but the peduncles have about the same size as those in Callorhinus and Monachus, and are relatively much smaller than in the bear.

The rhinal fissure is well developed. The olfactory peduncle for most of its length lies in this fissure. At the base of the peduncle the rhinal swerves obliquely in a caudo-lateral direction and is lost in the depths of the sylvian. It reaches a considerable depth under the presylvian lobe (sub-operculum).

The post rhinal is represented upon the ventral surface as a short spur or outcrop of the submerged postica, resembling in this respect the condition found in Zalophus, Callorhinus, and Monachus. In Ursus and Phoca the post rhinal is a continuation of the rhinal caudad of the sylvian.

Lateral aspect. - The sylvian points in the usual dorso-caudal direction on the lateral surface. It is a straight fissure, and does not bifurcate at its end. It measures 60 millimeters in length, and has a depth ranging from 20 to 30 millimeters. It is the deepest fissure of the brain, extending to within 5 millimeters of the lateral ventricle (paracœle). On opening the sylvian fissure one sees a fissure, the presupersylvian, quite near the lateral surface of the hemicerebrum. The two fissures run nearly parallel with each other, but diverge dorsally where the presupersylvian becomes an ordinary surface fissure. From three to six minor submerged fissures are found in the cephalic wall of the sylvian. These pass upward toward the surface, and some have a superficial connection with the presupersylvian, but the majority usually do not appear upon the lateral aspect of the brain. Submerged minor fissures also appear in the caudal wall of the sylvian. These in general have the 
same form and direction as those in the cephalic wall. One striking exception with regard to the direction of the submerged fissures I have called attention to in a preceding paper. ${ }^{a}$ This fissure I have compared with the postica. It corresponds to a fissure of the same name in the feline brain, but differs in this instance, in that it is submerged in the sylvian. Ursus, Zalophus, Callorhinus, and Phoca also show this peculiarity. The postica differs from the other submerged fissures of the sylvian by extending in a direction at nearly right angles to them, that is, dorso-ventrally, paralleling approximately for a short distance that of the sylvian itself.

The true insula is but scarcely developed in the walrus, and appears merely as a slight elevation in the bottom of the sylvian fissure. The submerged gyre formed by the postica fissure may easily be mistaken for a well-developed insula, as it has approximately a suitable location. Whether the submerged gyre later forms a closer relationship with the true insula, and is the precursor of the more complicated insula found in the higher forms, is a question that can not be answered here. Ziehen ${ }^{b}$ describes in the walrus a well-developed insula divided by fissures into three gyres.

Supersylvian fissure.-This fissure arches around the distal end of the sylvian in the usual way. Its frontal portion-the presupersylvian-passes close to the sylvian, converging gradually until near the base of the sylvian the presupersylvian becomes a submerged fissure, cropping out later to a slight extent upon the ventral surface. There is no evidence of a shallow or vadum indicating a separation of the presupersylvian and the supersylvian proper, as sometimes occurs in the fur seal. In Phoca the two fissures are entirely distinct and are without evidence even of a superficial connection. In the walrus the two fissures are continuous with each other, as in the dog and bear, and the differentiation is therefore an arbitrary one.

Perhaps the most puzzling feature regarding the fissures of this specimen of the walrus brain is the relationship of the supersylvian with the postsupersylvian. The conditions appear very much as in the brain of the sea lion (Zalophus). The apparent postsupersylvian is four times as far removed from the sylvian as is the presupersylvian. In this wide area between the sylvian and postsupersylvian Zalophus shows a few minor fissures extending horizontally. In the walrus there are also minor fissures present in this area but also a fairly welldeveloped fissure nearly vertical in its direction, almost connecting with the supersylvian on the right hemicerebrum, but totally disconnected on the left hemicerebrum. This vertical fissure seems to be too well developed to be classed with the minor fissures and its position and relations suggest the possibility of its being a poorly developed

$a$ Fish, The Brain of the Fur Seal (Callorhinus ursinus), Report of the Fur Seal Investigation, $1896-97$, pt. 3, pp. 21-40.

b Anatomischer Anzeiger, V, 1890, pp. 692-709. 
and disconnected postsupersylvian fissure. In the cat there is usually a disconnection between the supersylvian and postsupersylvian, and occasionally this disconnection is seen in Callorhinus and Monachus. On the other hand, the vertical fissure is much shallower than the supersylvian, and the latter is continuous with a deep and welldeveloped fissure apparently corresponding with the postsupersylvian of the sea lion, Phoca, bear, and dog.

The matter is further complicated by the fact that if this be regarded as the postsupersylvian, it is longer than usual, since it passes down from the lateral surface and appears upon the ventral aspect, and lies, in part, in the situation generally occupied by the ectolateral fissure. The ectolateral generally occupies a position between the postsupersylvian and lateral fissures; sometimes it connects with the lateral, but rarely with the postsupersylvian, although such a connection was once observed by me on the hemicerebrum of a young fur seal. The examination of a number of brains shows that the ectolateral is a more variable and inconstant fissure than the postsupersylvian, and in the present specimen of the walrus brain it seems safer to infer that the postsupersylvian and ectolateral have run together to form a long and continuous fissure and that the vertical fissure above mentioned is an unusually well-developed minor fissure. In the sea lion, where this region is so similar to that of the walrus, the postsupersylvian is a shorter fissure and is entirely disconnected from the ectolateral.

The sylvian gyre is that arch-like portion of the cortex around the sylvian fissure included within the boundary line formed by the supersylvian and pre- and post-supersylvian fissures. The cephalic limb of the gyre is narrow and completely submerged in the ventral third of the sylvian fissure. The caudal limb has a much greater area, being easily four times as wide as the cephalic. A few minor fissures branch out from the sylvian into this frontal limb. The caudal limb has a greater number of these fissures, and one in particular is developed to such an extent as to suggest the possibility of its representing the postsupersylvian.

Lateral fissure.-This fissure is unequally developed on the two hemicerebrums. The well-defined arch which it forms in some carnivorous and seal brains is not well represented in the walrus. On the left hemicerebrum it is apparently an interrupted fissure; a $p l i$ de passage or fold of cortex separates it a little in front of the level of the sylvian. From this point on it arches forwarc and downward. Caudally it does not extend beyond the level of the caudal end of the supersylvian. On the right hemicerebrum, instead of arching in a caudal direction it extends toward and nearly reaches the mesal surface. A short fissure having the direction the lateral should take is separated from the lateral proper by a narrow pli de passage. The lateral fissure of the sea lion accords quite closely with that of the walrus, in 
that its cephalic portion is much better developed than the caudal. In Ursus, Callorhinus, Phoca, and Monachus, on the other hand, the lateral is the longest fissure of the brain.

Ansate fissure.-No distinct line of separation exists in the walrus between the ansate and the lateral, and the separation into individual fissures is therefore an arbitrary one. A like condition exists in the sea lion, bear, and dog. In Phoca, Callorhinus, Monachus, and the cat some differentiation exists.

Coronal fissure.- In the left hemicerebrum of the walrus there is no line of demarcation between the coronal, ansate, and lateral fissures, and the three together appear as a long, continuous fissure reaching over upon the ventral aspect. On the right hemicerebrum the coronal is an independent fissure, being separated from the ansate by a pli de passage or isthmus 6 millimeters in width. On each hemisphere the extent of the coronal upon the ventral aspect is quite remarkable. It reaches nearly to the rhinal fissure just in front of the sylvian. In the bear and sea lion the relation of the coronal, ansate, and lateral fissures is quite similar to that of the walrus.

Supersylvian gyre.-This gyre surrounds the sylvian gyre and is bounded on the one side by the supersylvian and pre- and postsupersylvian fissures; on the other side by the coronal, ansate, and lateral fissures, and caudo-ventrally by a fissure which corresponds, in position, to the medilateral fissure. The frontal and dorsal portions of this gyre are well developed, averaging 30 millimeters in width. Numerous minor fissures, having a direction, in general, perpendicular to the boundary fissures, break up the supersylvian gyre into a number of secondary gyres. The caudal limb of the supersylvian tapers until it reaches a width of only about 20 millimeters, this condition probably being due to the extraordinary width (40 millimeters) of the sylvian gyre in this region.

Ectolateral fissure.-This fissure has already been discussed in connecion with the postsupersylvian fissure. In the allied forms studied the ectolateral may or may not extend over to the ventral surface of the brain. It may or may not connect either with the lateral or postsupersylvian, or lie between the two fissures. The fact that the postsupersylvian does not as a rule reach to any extent upon the ventral aspect makes it seem probable that if the ectolateral is at all represented upon the walrus brain it has fused with the postsupersylvian. On the left hemicerebrum it reaches nearly to the postrhinal fissure. On the right hemicerebrum it is shorter and a minor fissure intervenes.

Medilateral fissure. - In some forms the name is particularly appropriate if it has any connection with the relation of the fissure to the median and lateral aspects of the hemicerebrum. Its situation is never very far from the edge or margin separating these two aspects. 
In some cases it lies exactly along this margin (Monachus); in other cases it lies partly upon the lateral and partly upon the mesal surface (Callorhinus), or, as in Zalophus, it may be better seen upon the mesal aspect. In the walrus it is better seen upon the lateral aspect. On the left hemicerebrum it arches forward to the vertex, but does not quite reach the mesal margin. At this point another fissure 55 millimeters in length continues forward from the mesal margin in the same direction that the medilateral would take if it were longer. The inference is that it is properly a portion of the medilateral cut off by a narrow isthmus of the cortex.

Another fissure, 70 millimeters in length, separated (from the fissure just described) by an isthmus 13 millimeters, continues forward and downward upon the mesal aspect as far as the cruciate fissure, and has a slight superficial connection with it. The appearances indicate that the medilateral on the left hemicerebrum is divided into three portions - the caudal portion, 90 millimeters long, located on the lateral surface; the middle portion, 55 millimeters, lying in the margin between the mesal and lateral surfaces; and the cephalic portion, 70 millimeters long, lying entirely upon the mesal aspect. On the right hemicerebrum the medilateral lies upon the dorso-lateral aspect and begins far down on the caudal portion of the hemicerebrum, arching upward and forward as far as the vertex. It lies very close to the meso-lateral margin but recedes from it gradually until the vertex is reached. It is interrupted at this point by a cortical isthmus 5 millimeters wide. The cephalic portion of the fissure begins a little mesal to the termination of the caudal portion. As it arches forward and downward it recedes from the mesal margin and extends to a point a little beyond the cruciate. Turner ${ }^{a}$ figures the medilateral upon the lateral aspect of both hemicerebrums of the walrus as a long uninterrupted fissure, quite close to the mesal margin caudally but receding from it as it arches downward and forward. In my specimen the medilateral is divided into two portions on the right hemicerebrum, both lying on the dorsolateral surface. On the left hemicerebrum it is divided into three portions and the frontal portion lies upon the mesal surface. If it were a continuous fissure it would be by far the longest fissure of the brain.

Cruciate fissure. This fissure just cuts through the mesal margin and extends only 12 millimeters upon the frontal portion of the lateral surface. On the left hemicerebrum there is a postcruciate fissure, triradiate in form, represented. The precruciate is not well represented except by a short fissure lying in the mesal margin, which fuses into the cruciate. On the right hemicerebrum the postcruciate is not represented as a distinct fissure. It may have become fused

$a$ Report on the seals collected during the voyage of H. M. S. Challenger, in the years 1873-1876, Zoology, XXVI, 1888, pp. 89-134. 
with the medilateral, which at this point has a superficial connection with the cruciate. There is no distinct evidence of a precruciate upon this hemicerebrum. On this account there is no area that may be correlated in any way with the "Ursine Lozenge" thought by Mivart to be of considerable importance in showing a relationship between the seals and the carnivora. In the walrus the cruciate area is quite similar to that of Phoca. In Monachus a slight or rudimentary "Ursine Lozenge" may be detected. In Ursus, Callorhinus, and Zalophus the "lozenge" is well developed. The sigmoid gyre surrounds the frontal portion of the cruciate fissure.

Superorbital fissure.-This fissure occupies the usual position upon the ventro-lateral surface of the frontal portion of the brain. On the left hemicerebrum it is about 50 millimeters in length. It arises near the rhinal fissure not far from the base of the olfactory peduncle. It curves laterally and then back again toward the mesal aspect so that its termination is covered by the olfactory bulb. At the lower third of its course it gives off a short and very superficial lateral branch. On the right hemicerebrum the fissure is very similar to that on the left, except that the lateral branch is much smaller.

Lateral gyre (Mediolateral convolution of Turner).-In the present specimen this gyre is not well represented upon the caudal portion of the brain. The short length of the lateral fissure brings about the unusual condition of having the mediolateral fissure form a portion of the boundary of the supersylvian gyre. In this case, therefore, the medilateral gyre begins well up toward the vertex in a tapering manner and gradually becomes wider as it arches toward the frontal portion of the brain, attaining a width of from 30 to 40 millimeters in its widest parts. Like the supersylvian gyre, it contains a number of minor fissures.

Marginal or sagittal gyre.-On the left hemicerebrum this is a very narrow gyre and is represented only on the caudal portion. It disappears at the vertex. This disappearance is due to the fact that the frontal portion of the interrupted medilateral fissure lies upon the mesal aspect. Two or three traces of minor fissures appear in the left saggittal gyre. On the right hemicerebrum the gyre has a fair width in its caudal portion, but becomes narrower, until at the vertex it almost disappears, but it gradually widens again until in the frontal portion it attains the width of 17 millimeters. On this hemicerebrum there are a number of quite well-developed minor fissures present, which in almost every instance extend over upon the mesal surface.

Pre and post sylvian areas. - The post sylvian region comprises the unusually wide caudal limb of the sylvian gyre, the supersylvian gyre, and the narrow marginal (or sagittal) gyre. The presylvian region includes the very narrow frontal limb of the sylvian gyre, and the wide frontal limbs of the supersylvian and medilateral gyres. On the

Proc. N. M. vol. xxvi-02-46 
right hemicerebrum the marginal gyre should be included. The presylvian has a greater area than the postsylvian region. The former is made up mostly of the medilateral and supersylvian gyres and the latter by the sylvian and supersylvian gyres.

\section{MESAL ASPECT.}

Hippocampal fissure.-This occupies the usual position. It is seen arching from the splenium of the callosum around the optic thalamus to the tip of the pyriform or temporal lobe.

Callosal fissure.-As its name indicates, it is closely related to the callosum. It separates the callosum from the adjacent cortex. It is deepest in the region of the splenium and gradually grows shallower until as it curves around the genu it becomes flush with the surface. On the right hemicerebrum it diverges somewhat from the genu of the callosum.

Splenial fissure.-This fissure is well developed in the walrus and occupies the usual position upon the tentorial surface of the brain. It arches upward and forward, curving around the splenium on the mesal surface. On the right hemicerebrum it is a continuous fissure and extends as far as the frontal portion of the callosum; it then extends upward almost vertically nearly to the dorsal margin of the hemicerebrum. On the left hemicerebrum the fissure is interrupted. Its tentorial portion stops at the level of the splenium. The mesal portion begins as two small superficial fissures converging in a fork-like manner to form the mesal splenial proper. At the level of the genu it terminates in a fork, the lower branch passing nearly to the frontal margin of the hemicerebrum. In neither case did the splenial connect with the cruciate, as described by Turner in his specimens. On the right hemicerebrum there was a slight indication of a superficial connection, but a submerged gyre or buttress shut off any free communication.

Hippocampal gyre. - This gyre lies upon the tentorial surface of the brain. It forms the most of the mesal portion of the pyriform or hippocampal lobe. It take; the same general direction as the hippocampal fissure (which forms its sphalic or inner boundary), arching upward to the level of the splei im. Its caudal boundary is formed by the tentorial portion of the sylenial fissure. The hippocampal gyre averages 15 millimeters in width and possesses a few minor fissures, which in the main are offshoots from the splenial and have a horizontal direction. On the left hemicerebrum, lyıng in the hippocampal gyre just caudal to the splenium, is a vfry shallow sulcus corresponding in position to the fissura sublımica Kükenthal. It is not noticeable upon the right hemicerebrum.

Callosal gyre.-This, as the pame indicates, lies just dorsal to the callosum. It is a narrow gyre and its average width is about 10 milli- 
meters. Only one or two faint traces of minor fissures are evident. It is the simplest gyre of the brain and is continuous with the hippocampal gyre around the splenium of the callosum.

Presplenial fissure. - This fissure is not well represented on either hemicerebrum of the walrus. On the right hemicerebrum a shallow and short vertical fissure may indicate it. On the left hemicerebrum the only representative of it would be the upper branch of the frontal portion of the splenial. Neither Turner nor Ziehen figures or describes its presence. The fissura sublimica anterior is not shown at all unless, as in Kükenthal's diagram, it is confused with the cruciate.

Postsplenial fissure.--In Phoca and Callorhinus the tentorial portion of the splenial terminates in a bifurcation, the caudal horizontal branch of which is called the post splenial. This is not the case in my specimen of the walrus brain. Respecting this region in the walrus, Turner says:

Behind and below the end of the specimen the splenial fissure gave off a posterohorizontal fissure, which, running horizontally backward, extended almost to the posterior border of the hemisphere. * * * The post-splenial fissure of Krueg was situated behind the ascending part of the splenial fissure and ran backward and upward nearly to the posterior border of the hemisphere below the postero-horizontal fissure. It was separated from the splenial fissure by the splenial convolution, which is consequently bounded in front by the splenial and behind by the post-splenial fissure.

On the left hemicerebrum of my specimen there is a small fissure 15 millimeters in length which corresponds in position to the posterohorizontal of Turner. On the right hemicerebrum a mere spur 5 millimeters long from the splenial represents it.

With regard to the post splenial there is found on the right hemicerebrum a well-developed vertical fissure branching out of the splenial not far from its tentorial origin. This I regard as the post-splenial fissure, although its direction is vertical anc not horizontal. On the left hemicerebrum there is no connection hetween the splenial and what I regard as the post splenial. The fissifre is not so well developed as that described by Turner, unless in : y specimen it is an interrupted fissure. An unnamed but well-dev sioped fissure extending dorsally is separated from what I consider the post splenial by a cortical isthmus of only 4 millimeters' width. The fappearances suggest an interrupted fissure. Turner does not des r w any connection between the post-splenial and splenial fissures, but calls the intervening space the splenial convolution (gyre).

Marginal fissure.-In Zalophus, Phor, and Callorhinus this is a well-developed fissure lying between, a: approximately parallel with, the splenial and medilateral fissures. ' seems to correspond in many cases with the suprasplenial fissure of i. ueg, and in some special cases with the combined post and supra snlenial of the same author. In the walrus the marginal is not especially well developed. On both 
hemicerebrums there is a fair-sized fissure occupying the proper location. The appearances are very suggestive of those in Monachus, where the fissure is relatively short and undeveloped and sometimes appears interrupted. On the left hemicerebrum where the splenial is interrupted there is a fissure dorsal to, and running parallel with, the callosal portion of the splenial. From its position the name suprasplenial would be very appropriate, although in some respects it differs from Krueg's. On the right hemicerebrum it is not represented.

Marginal gyre.-This, in general, refers to the cortical area lying between the splenial and medilateral fissures, and would therefore include, in the walrus, the dorsal margin of the hemicerebrum, on account of the extended development of the medilateral fissure. What I have described as the marginal fissure lies within this gyre. and the name therefore seems appropriate.

Collateral fissure. - This fissure appears upon the tentorial surface, and is perhaps best seen on the ventral or mesal aspect. Its form is somewhat arched, and it lies ventrally to the origin of the splenial. It begins not far from the hippocampal, and its termination caudally is usually more or less closely associated with either the lateral or medilateral fissure, so that in some eases, at least, it may appear upon the ventro-lateral aspect of the hemicerebrum.

Genial fissure.-This is commonly a shallow fissure, lying in front of and is more or less closely associated with the genu of the callosum, from which fact it takes its name. It is found in both hemicerebrums of the walrus. On the left it has a short frontal branch which connects superficially with an unnamed minor fissure. On the right hemicerebrum it is farther removed from the genu, and ventrally it fuses with the rostral fissure.

Rostral fissure. - This is also a shallow fissure and lies nearer to the frontal margin of the hemicerebrum. On the left it is a straight fissure 30 millimeters long. On the right hemicerebrum it is of the same length, and its dorsal end reaches the margin. On account of the convergence of the rostral and genual fissures the basal or ventral third represents a combination of these two fissures.

The lateral ventricle (paracoele). - On removing the dorsal portion of the hemicerebrum just dorsal to the callosum the lateral ventricle is revealed. The cavity dips cephalo-ventrad, ending blindly, to form the precornu; it also dips caudo-latero-ventrad to form the medicornu. The striatum (caudate nucleus) is a convex and well-defined body forming the most of the floor and lateral side of the precornu. Parallel with the oblique caudal margin of the striatum is the fimbrial margin of the hippocamp, which, extending down into the medicornu, forms with the hippocamp the floor of this cavity. Between these two margins (striatum and fimbria) - the rima (great transverse fissure), the choroid (para) plexus - a continuation of the velum enters the floor of the medicornu. The rima is narrow and the thalamus does not 
appear at all in the floor of the ventricle. A slight caudal projection of the cavity, at the beginning of the medicornu, extending just beyond the level of the splenial fissure, represents the postcornu. In his dissection of the walrus brain, Turner shows no indication of a postcornu, but in the text he states: "Where the cavity of the ventricle curved downward and outward into the horn, an indication of a recess was seen in its posterior horn, but it did not amount to a cornu and there was no elevation which could be called a hippocampus minor." In Ursus there is no postcornu. In Callorhinus a slight caudal spur of the cavity indicates its position. Zalophus was not examined in this region. In Monachus there is a fairly well-developed postcornu. Murie describes a well-developed postcornu in the Manatee and Otaria, and in both a well-developed hippocampus minor or calcar. In Phoca vitulina the postcornu is relatively large, and the hippocampus minor is well developed, being correlated with the splenial fissure and making of it, for a portion of its course at least, a total fissure.

Terminology.-A difficulty of some importance is the selection of the terms to be employed in the description of the fissures and gyres, particularly in the brain of the Pinnipedia, where the literature is not especially abundant. The literature on the carnivorous brain is more extensive, but as many authors have employed terms of their own without reference to the nomenclature used by others, some confusion has naturally resulted. It has therefore seemed best in the present case not to follow the terminology of any one author, but to use those terms which, by their special fitness, seemed most appropriate. On this account the priority of terms has not been especially considered, for in some cases later investigations have shown that some of the earlier terms were not the best to use in considering the homologies between the various forms.

Some of the more common synonyms of the names of the various fissures used in this article are as follows: The supersylvian is very commonly called the suprasylvian. Turner and Gratiolet have apparently confused this fissure with the lateral in Phoca. I have preferred the term postsupersylvian, as used by Krueg, Turner, and others, to postsylvian, as recommended by Owen and Wilder. The term presupersylvian has been introduced to apply to what is commonly described as the anterior or frontal portion of the supersylvian or the ectosylvia antiea of Ziehen. The superorbital of Flower and Wilder is preferred to the intraorbital of Turner and Langley. This fissure has also been designated as the presylvian by Krueg and others. The term presylvian has also been applied by some writers to describe what commonly appears to be the coronal fissure. Cruciate is retained, as is done by most writers, although frontal fissure is the term originally suggested by Owen. I have also employed the term marginal fissure, as used by Owen and Wilder, instead of suprasplenial, as used by Krueg and Turner. 


\section{SUMMARY.}

After obliterating the numerous minor fissures and the branches of the principal fissures from the cerebrum of the walrus there is left a very good fissural pattern resembling, in general, the typical arrangement of the fissures in the brain of carnivorous animals. As in the cat, dog, and bear, the presylvian area is greater in length than the postsylvian. In the sea lion the two areas are about equal. In Monachus, Callorhinus, and Phoca the postsylvian area is longer than the presylvian.

The epiphysis is very highly developed in the walrus, and in the seals it is much better developed than in carnivora. The olfactory bulbs and peduncles resemble those of the seals and do not attain as relatively great development as in carnivora. The postrhinal resembles the conditions in Zalophus, Callorhinus, and Monachus. The fissure postica resembles that of Ursus, Zalophus, Callorhinus, and Phoca. The supersylvian resembles that of the $\log$ and bear. The postsupersylvian is correlated more closely with that of Zalophus than in any of the other forms studied. The ectolateral, by fusing with the postsuperylvian, differs from any of the-other forms. The lateral fissure corresponds with Zalophus in that it is relatively short. The ansate fissure resembles the condition found in Zalophus, Ursus, and Canis. The coronal is quite similar to that in Ursus and Zalophus. The medilateral differs from that of the other forms in that it is interrupted; if considered as a continuous fissure it would be the longest fissure of the brain. The cruciate resembles the conditions found in Phoca and Monachus. The splenial accords more closely with the conditions found in Zalophus and Monachus. The marginal fissure resembles that of Monachus; it is not especially well developed. The development of the postcornu suggests a condition between that found in Callorhinus on the one hand and Monachus on the other.

As a matter of convenience, a table of the more important regions in the representatives of the different groups examined is herewith appended:

\begin{tabular}{|c|c|c|c|c|c|c|c|}
\hline No. & Region. & Ursus. & Callorhinus. & Zalophus. & Rosmarus. & Monachus. & Phoca. \\
\hline 1 & $\begin{array}{c}\text { S u b fi ssure } \\
\text { postica (?) }\end{array}$ & Present. & Present..... & Present..... & Present..... & Not very & Present. \\
\hline 2 & Postrhinal.. & $\begin{array}{l}\text { Continua- } \\
\text { tion of } \\
\text { rhinal, } \\
\text { ex e e } \\
\text { tionally } \\
\text { postica. }\end{array}$ & $\begin{array}{l}\text { Conneets } \\
\text { with pos- } \\
\text { tica. }\end{array}$ & $\begin{array}{l}\text { Connects } \\
\text { with pos- } \\
\text { tica. }\end{array}$ & $\begin{array}{l}\text { Connects } \\
\text { with pos- } \\
\text { tica. }\end{array}$ & $\begin{array}{l}\text { Mere trace, } \\
\text { very su- } \\
\text { perficial, } \\
\text { con nec- } \\
\text { tion with } \\
\text { postica. }\end{array}$ & $\begin{array}{l}\text { Contin ua- } \\
\text { tion of rhi- } \\
\text { nal. }\end{array}$ \\
\hline 3 & $\begin{array}{l}\text { Presuper- } \\
\text { sylvian. }\end{array}$ & $\begin{array}{l}\text { Continuous } \\
\text { with su- } \\
\text { persy l- } \\
\text { vian. }\end{array}$ & $\begin{array}{l}\text { Sometimes } \\
\text { dis c o n- } \\
\text { nected. }\end{array}$ & Continuous. & Continuous. & Continuous. & $\begin{array}{l}\text { Disconnect- } \\
\text { ed. }\end{array}$ \\
\hline 4 & $\begin{array}{l}\text { Postsuper- } \\
\text { sylvian. }\end{array}$ & $\begin{array}{l}\text { Continuous } \\
\text { with su- } \\
\text { pers y l- } \\
\text { vian. }\end{array}$ & $\begin{array}{l}\text { May or may } \\
\text { notbecon- } \\
\text { tinuous. }\end{array}$ & Continuous. & Continuous. & $\begin{array}{l}\text { May or may } \\
\text { not becon- } \\
\text { tinuous. }\end{array}$ & $\begin{array}{l}\text { Usually con- } \\
\text { tinuous. }\end{array}$ \\
\hline
\end{tabular}




\begin{tabular}{|c|c|c|c|c|c|c|c|}
\hline No. & Region. & Ursus. & Callorhinus. & Zalophus. & Rosmarus. & Monachus. & Phoca. \\
\hline 5 & Precruciate. & Mostly dor- & Dorsal .. & Dorsal .. & $\begin{array}{l}\text { Presence } \\
\text { doubtful. }\end{array}$ & $\begin{array}{c}\text { Mesal and } \\
\text { dorsal. }\end{array}$ & Not clearly \\
\hline 6 & Cruciate.... & Dorsal...... & Dorsal ... & Dorsal. & $\begin{array}{c}\text { Mesal and } \\
\text { dorsal. }\end{array}$ & $\begin{array}{l}\text { Mesal and } \\
\text { dorsal. }\end{array}$ & $\begin{array}{l}\text { Mesal and } \\
\text { dorsal. }\end{array}$ \\
\hline 7 & Posteruciate & Present. & Present.. & Present.... & $\begin{array}{l}\text { Sometimes } \\
\text { not dis- } \\
\text { tinct. }\end{array}$ & $\begin{array}{l}\text { Rud imen- } \\
\text { tary. }\end{array}$ & Present. \\
\hline 8 & Medilateral. & Present.... & Present.... & Present.... & $\begin{array}{l}\text { Long and } \\
\text { dis con- } \\
\text { nected. }\end{array}$ & Present..... & $\begin{array}{l}\text { A series of } \\
\text { small dis- } \\
\text { connected }\end{array}$ \\
\hline 9 & Marginal ... & Absent .... & Present..... & Present..... & Present.... & $\begin{array}{c}\text { Short, inter- } \\
\text { r u p t e d } \\
\text { fissures }\end{array}$ & $\begin{array}{l}\text { nssures. } \\
\text { Present. }\end{array}$ \\
\hline 10 & Collateral .. & Absent .... & Present..... & $\begin{array}{l}\text { Rudimen- } \\
\text { tary. }\end{array}$ & Present..... & Present..... & Present. \\
\hline 11 & $\begin{array}{l}\text { Minor fis- } \\
\text { sures. }\end{array}$ & Rare. & $\begin{array}{l}\text { Quite nu- } \\
\text { merous }\end{array}$ & Not many .. & Numerous .. & $\begin{array}{l}\text { Quite nu- } \\
\text { merous. }\end{array}$ & $\begin{array}{l}\text { Quite nu- } \\
\text { merous. }\end{array}$ \\
\hline 12 & $\begin{array}{l}\text { "U r s i n e } \\
\text { Lozenge." }\end{array}$ & Presel & Present..... & Present. & Not distinet. & Small....... & Absent. \\
\hline 13 & Postcornu .. & Absent ..... & $\begin{array}{l}\text { Rudimen- } \\
\text { tary. }\end{array}$ & (?) & Small....... & Fair size.... & Large. \\
\hline 14 & $\begin{array}{l}\text { C a l c a r. } \\
\text { (H i p p- } \\
\text { c a m pus } \\
\text { minor.) }\end{array}$ & Absent & Absent .... & (?) & Absent.... & Indistinct .. & $\begin{array}{l}\text { Very dis- } \\
\text { tinct. }\end{array}$ \\
\hline 15 & Insula ..... & Slight... . & Slight ...... & Slight ..... & Slight . .... & Slight ...... & Slight. \\
\hline 16 & $\begin{array}{l}\text { Pre and } \\
\text { post sylvi- } \\
\text { an areas. }\end{array}$ & $\begin{array}{l}\text { Presylvian } \\
\text { area lon- } \\
\text { ger. }\end{array}$ & $\begin{array}{c}\text { Postsylvian } \\
\text { longer. }\end{array}$ & $\begin{array}{l}\text { The t w o } \\
\text { areas ap- } \\
\text { p r o x i- } \\
\text { matel y } \\
\text { equal. }\end{array}$ & $\begin{array}{l}\text { Presylvian } \\
\text { area lon- } \\
\text { ger. }\end{array}$ & $\begin{array}{l}\text { Postsylvian } \\
\text { longer. }\end{array}$ & $\begin{array}{l}\text { Postsylvian } \\
\text { longer. }\end{array}$ \\
\hline
\end{tabular}

\section{BIBLIOGRAPHY.}

In the preparation of this article I have made free use of the following works:

1899. Fish, P. A. The Brain of the Fur Seal, etc. Report of Fur Seal Investigations, $1896-97$, Pt. 3, pp. 21-41; also Journal of Comparative Neurology, VIII, 1898, pp. 57-98.

1899. Flatau and $J_{\text {ACobsohn. Anatomie des Centralnerven-Sys- }}$ tems, I.

1880. Krueg, Julius. Ueber die Furchen auf der Grosshirnrinde der zonoplacentalen Säugethiere. Zeitschrift für wissenschaftliche Zoologie, XXXIII, pp. 595-672.

1889. Kükenthal, Willy. Untersuchungen an Waltieren.

1888. Turner, Sir William. Brain of Elephant Seal, and Walrus. H. M. S. Challenger Report, 1873-1876, Zoology, XXVI, Pt. 3, pp. 89-134; also Journal of Anatomy, XXV, 1891, pp. 105-153.

1886. Wilder, B. G., and Gage, S. H. Anatomical Technology.

1890. Zienen, Theodor. Zur vergleichenden Anatomie der Hirnwindungen mit spezieller Berücksichtigung der Gehirne von Ursus maritimus und Trichecus rosmarus. Anatomischer Anzeiger, V, pp. $692-709$.

For a more complete bibliography of literature pertaining to the brain of the Carnivora and Pinnipedia, consult the work of Flatau and Jacobsohn or Turner's Challenger Report. 
EXPLANATION OF PLATES.

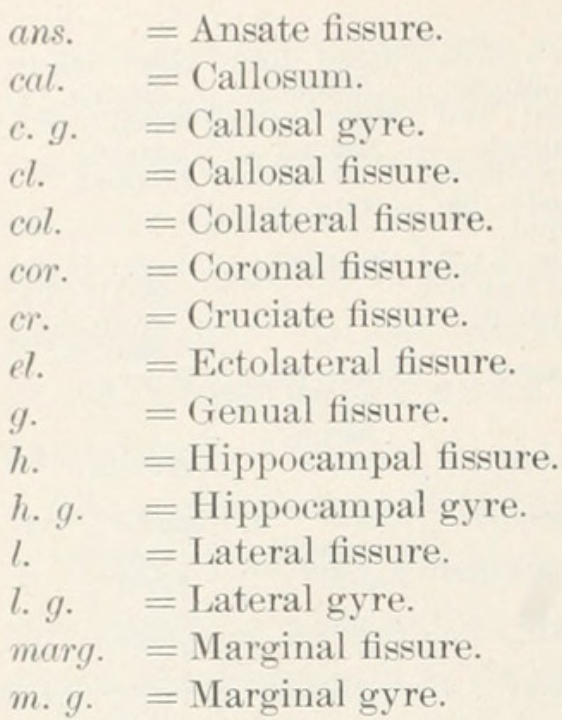

ml. $\quad=$ Medilateral fissure.

por $\quad=$ Postcruciate fissure.

ph. $\quad=$ Postero-horizontal fissure

prspl. $=$ Presplenial fissure.

prss. $\quad=$ Presupersylvian fissure.

pspl. = Postsplenial fissure.

pss. $\quad=$ Postsupersylvian fissure.

$r . \quad=$ Rostral fissure.

so. $=$ Superorbital fissure.

$s p l . \quad=$ Splenial fissure

syl. = Sylvian fissure.

ss. $=$ Supersylvian fissure.

syl. $g .=$ Sylvian gyre

ss. g. = Supersylvian gyre.

\section{Plate XXViII.}

Fig. 1. Lateral aspect of the left hemicerebrum of Rosmarus rosmarus. The various fissures were sounded and the numbers represent the depth in millimeters of the fissure at that point.

Fig. 2. Lateral aspect of the right hemicerebrum of Rosmarus rosmarus. The numbers represent the sounding of the fissures as in fig. 1 .

\section{Plate XXiX.}

Fig. 3. Mesal aspect of the left hemicerebrum of Rosmarus rosmarus.

Fig. 4. Mesal aspect of the right hemicerebrum of Rosmarus rosmarus. 


\section{$2 \mathrm{BHL}$ Biodiversity Heritage Library}

Fish, Pierre A. 1903. "The cerebral fissures of the Atlantic walrus." Proceedings of the United States National Museum 26(1325), 675-688.

https://doi.org/10.5479/si.00963801.26-1325.675.

View This Item Online: https://www.biodiversitylibrary.org/item/32571

DOI: https://doi.org/10.5479/si.00963801.26-1325.675

Permalink: https://www.biodiversitylibrary.org/partpdf/9442

\section{Holding Institution}

Smithsonian Libraries

\section{Sponsored by}

Smithsonian

\section{Copyright \& Reuse}

Copyright Status: NOT_IN_COPYRIGHT

This document was created from content at the Biodiversity Heritage Library, the world's largest open access digital library for biodiversity literature and archives. Visit BHL at https://www.biodiversitylibrary.org. 